AneKonda, T. S. and W. T. AdAms (2000): Cold hardiness testing for Douglas-fir tree improvement programs: guidelines for a simple, robust and inexpensive screening methos. Western Journal of Applied Forestry. 15(3): 129-136.

Bello-Lara, A. and J. Cibrián-Tovar (2000): Evaluación técnica de la reforestación 1998. In: Proceedings of the 1er. Congreso Nacional de Reforestación. Montecillo, Texcoco, México.

Binder, W. D., P. Fielder, G. H. Mohammed and S. J. L'HIRONDELLE (1997): Applications of chlorophyll fluorescence for stock quality assessment with different types of fluorometers. New For. 13: 63-89.

CAMPBELL, R. K (1979): Genecology of Douglas-fir in a watershed in the Oregon Cascades. Ecology 60: 1036-1050.

Farjon, A. and B. T. Styles (1997): Pinus (Pinaceae). Flora Neotropica. Monograph 75. New York Botanical Garden, New York.

GARCíA, E. (1988): Modificaciones al sistema de clasificación climática de Köppen. UNAM, México D.F., 217 p.

MusÁlem, M. A. and O. SÁNCHez-CRUZ (2003): Monografía de Pinus michoacana Martínez. SAGARPA-INIFAPCONABIO, Chapingo, México.

PERRY, J. P. (1991): The pines of México and Central America. Timber Press, Portland Oregon, $231 \mathrm{p}$.

O’NeILL, G. A. (1999): Genetics of fall, winter and spring cold hardiness in coastal Douglas-fir seedlings. Ph.D. Dissertation. Oregon State University, Corvallis, Oregon.

REHFELDT, G. E. (1980): Cold acclimation in populations of Pinus contorta from the northern Rocky Mountains. Bot. Gazette. 141: 458-463.

REHFELDT, G. E. (1983a): Seed Transfer guidelines for Douglas-fir in western Montana. USDA For. Serv. Res. Note INT-329.

REHFELDT, G. E. (1983b): Seed Transfer guidelines for Douglas-fir in Central Idaho. USDA For. Serv. Res. Note INT-337.

REHFELDT, G. E. (1985): Ecological genetics of Pinus contorta in the lower Snake River Basin of central Idaho. USDA For. Serv. Res. Pap. INT-354.

REHFELDT, G. E. (1988): Ecological genetics of Pinus contorta from the Rocky Mountains (USA): a synthesis. Silv. Genet. 37: 131-135.
REHFELDT, G. E. (1989): Ecological adaptations in Douglas-fir (Pseudotsuga menziesii var. glauca): a synthesis. For. Ecol. Manage. 28: 203-215.

REHFELDT, G. E. (1991): A model of genetic variation for Pinus ponderosa in the Inland Northwest (USA): applications in gene resource management. Can. J. For. Res. 21: 1491-1500.

RosenBerb, N. J. (1974): Microclimate: the biological environment. Wiley and Sons, New York.

SÁENZ-Romero, C. (2004a): Zonificación estatal y altitudinal para la colecta y movimiento de semillas de coníferas en México. In: VARGAS-HeRnández, J. J., BERMEJoVelázquez, B. and Ledig, F. T. (Eds.). Manejo de Recursos Genéticos Forestales. CONAFOR-Comisión Forestal de América del Norte, México. pp. 72-86.

SÁenZ-Romero, C. (2004b): Zonificación y conservación de coníferas en México. In: Vera C., G., VARGAs H. J. and Dorantes L. J. (Ed.). Uso y Conservación de Recursos Genéticos Forestales. Comisión Nacional Forestal, México. pp. 21-28.

SÁenz-Romero, C., A. Snively and R. Lindig-Cisneros (2003): Conservation and restoration of pine forest genetic resources in México. Silv. Genet. 52(5-6): 233-237.

SÁenz-Romero, C. and R. Lindig-Cisneros (2004): Evaluación y propuestas para el programa de reforestación en Michoacán, México. Ciencia Nicolaíta 37: 107-122.

Sáenz-Romero, C., R. R. Guzmán-Reyna and G. E. ReHFELDT (2006): Altitudinal genetic variation among Pinus oocarpa populations in Michoacán, México; implications for seed zoning, conservation of forest genetic resources, tree breeding and global warming. For. Ecol. Manage. 229: 340-350.

SAS INSTITUTE INC. (1988): SAS/STAT Guide for personal computers. Version 6.03. SAS Institute Inc., Raleigh, North Carolina, USA.

ShorTt, R. L., B. J. Hawkins and J. H. Woods (1996): Inbreeding effects of the spring frost hardiness coastal Douglas-fir. Can. J. For. Res. 26: 1049-1054.

St.ClAIR, J. B. (2006): Genetic variation in fall cold hardiness in coastal Douglas-fir in western Oregon and Washington. Can. J. Bot. 84: 1110-1121.

\title{
Evaluation of Provenances of Eucalyptus camaldulensis and Clones of E. camaldulensis and E. tereticornis at Contrasting Sites in Southern India
}

\author{
By M. VARGHESE ${ }^{1)}$, C. E. HARWood ${ }^{2)}$, R. Hegde $^{1)}$ and N. Ravi ${ }^{1)}$
}

(Received 22 $2^{\text {th }}$ January 2007)

\begin{abstract}
A total of 188 open-pollinated families of Eucalyptus camaldulensis Dehnh. from 18 Australian natural

\footnotetext{
1) Institute of Forest Genetics and Tree Breeding (IFGTB), Coimbatore - 641002, India. Email: mvarghese1@rediffmail.com

2) CSIRO Sustainable Ecosystems, Private Bag 12, Hobart 7001, Australia.
}

provenances and 15 selected Indian families of the "Mysore Gum" land race were evaluated in three provenance-family trials at contrasting sites in southern India. At two years of age, the fastest growth was recorded at the driest site in Tamil Nadu, where $E$. camaldulensis provenances from Queensland were superior to those from Northern Territory and Western Australia, and the Indian land race. Provenance differ- 
ences were less pronounced at the two higher-rainfall sites in Andhra Pradesh and Kerala. Interaction of provenance performance with site was significant. Within-provenance individual-tree heritabilities for height and diameter at breast height (dbh) were low at the three individual sites, ranging from $0.08 \pm 0.05$ to $0.19 \pm 0.05$ for height and $0.10 \pm 0.05$ to $0.19 \pm 0.04$ for dbh. Across-site heritabilities, $0.07 \pm 0.02$ for both height and $\mathrm{dbh}$, were lower than those at individual sites. Phenotypically superior trees were selected from these trials and seven other plantings of $E$. camaldulensis and Eucalyptus tereticornis Smith in southern India and cloned from basal coppice. A total of $78 \mathrm{E}$. camaldulensis and $27 \mathrm{E}$. tereticornis selections, together with thirteen commercially planted Eucalyptus clones and five superior natural provenance seedlots, were tested in clonal trials at three sites in southern India, the different individual treatments being tested at from one to three sites. Three years after planting, most clones selected from E. camaldulensis trials and the commercial Eucalyptus clones were superior in volume production to $E$. tereticornis clones and seedling controls at a dry site in Tamil Nadu. A smaller number of clones, particularly those of $E$. camaldulensis, were also superior to seedling controls at an intermediate-rainfall site in Andhra Pradesh. At a third high-rainfall site in Kerala, seedling controls were superior to all but four of 46 clones tested. Significant clone-by-site interaction was observed for growth traits. At the dry site in Tamil Nadu, clones varied widely in their wood basic density from 450 to 700 $\mathrm{kg} \mathrm{m}^{-3}$, and there was no significant correlation of clonal values for growth and wood density. The results confirm that clones are best selected and tested in environments similar to those where they will be deployed.

Key words: Eucalyptus camaldulensis, E. tereticornis, clone, provenance trial, deployment, genotype-by-environment interaction.

\section{Introduction}

The total area of eucalypts planted in India is estimated to exceed 2,500,000 ha (DEwEEs and SAXENA, 1995; MidGLey et al., 2002). Several pulp and paper mills, forest departments and forest development corporations have substantial areas of plantations either directly under their control or in farmers' land from which wood is purchased. Most eucalypt plantations across India are of 'Mysore Gum', a land race considered to be a mixture of pure Eucalyptus tereticornis Smith and genetic segregates of interspecific hybrids, displaying high variability (KAIKINI, 1961). The growth of Mysore Gum is quite slow, with mean annual increment of plantations averaging around $7 \mathrm{~m}^{3} \mathrm{ha}^{-1}$ (Chandra et al., 1992), and a number of trials have demonstrated superior performance of certain new eucalypt introductions (VARGHESE et al., 2001) or selected eucalypt clones (LAL et al., 1993). Eucalypts are the major raw material of the pulp and paper industries in India, so it is imperative that planting stock of high genetic quality be used to increase the yield from plantations. Much of the land available for planting eucalypts in southern India experiences a tropical climate with mean annual rainfall of less than $1000 \mathrm{~mm}$ and a long hot dry season of more than six months, leading to poor performance and survival of eucalypt species such as $E$. grandis Hill ex Maiden, E. urophylla S.T. Blake and their interspecific hybrid, which are widely planted and highly productive in higher-rainfall environments in Latin America (ELDRIDGE et al., 1993) and southern China (WEI and BorallHo, 1993).

Systematic genetic improvement programs for Eucalyptus camaldulensis Dehnh. and E. tereticornis in southern India coordinated by the Institute for Forest Genetics and Tree Breeding (IFGTB) commenced in 1995 with fresh introductions of a wide genetic base from natural provenances of these species (DoRAN et al., 1996). Unpedigreed multi-provenance seed production areas (SPAs) of the two species were established using bulked seedlots that combined more than 500 seed trees from several major tropical natural provenances. Provenance resource stands (PRSs) of three Queensland provenances of $E$. camaldulensis, Kennedy River, Morehead River and Laura River (DORAN and BuRGESS, 1993) were also planted using bulked seed of these individual provenances. These SPAs and PRSs have been selectively thinned to remove phenotypically inferior trees and now function as seed production areas. Progeny trials were established using family seedlots collected from selections made in existing southern Indian provenance trials of both species (VARGHESE et al., 2001). At the same time, new provenance-progeny trials of $E$. camaldulensis were planted at three locations to establish a broad, pedigreed genetic base for the breeding program. Smaller progeny trials of E. tereticornis were also planted. These trials were evaluated two years after planting to study provenance and family performance and to identify suitable provenances for each location (VARGHESE et al., 2000). After evaluation, the trials were selectively thinned for conversion to first generation seedling seed orchards (SSOs). The SSOs, SPAs and PRSs incorporate many thousands of trees of known natural provenance. Together, they comprise a large base and breeding population for genetic improvement of $E$. camaldulensis and $E$. tereticornis in southern India.

Apart from the production of high-quality seed and ongoing genetic improvement of the breeding populations, the improvement program also envisages deployment of outstanding individual selections in clonal plantations. Superior trees of E. camaldulensis and $E$. tereticornis were identified either in the provenanceprogeny trials described above using index selection, or in SPAs and PRSs using phenotypic selection (HEGDE and VARGHESE, 2002). These trees were clonally propagated and tested to select promising clones which might out-perform seed of the best natural provenances and clones that were commercially available from other improvement programs (KULKARNI, 2002). This paper summarizes the early performance of the pedigreed breeding populations of $E$. camaldulensis and the tested clones at contrasting sites in southern India, and considers the effectiveness of the genetic improvement strategy being followed.

\section{Materials and Methods}

\section{Provenance-progeny trials}

A total of 188 open-pollinated families of Eucalyptus camaldulensis belonging to 18 natural provenances rep- 
resenting three distinct geographical regions of Australia (eleven provenances from Queensland, four from Western Australia and three from Northern Territory) were raised for establishment of provenance-progeny trials in 1996 (Table 1, Figure 1). Open-pollinated families from fifteen selected trees of the Mysore Gum land race were included in two of the trials, which were established at three locations in Kerala, Tamil Nadu and Andhra Pradesh states in southern India, testing 182, 176 and 132 entries respectively (Table 2). The trials used randomized alpha designs with row and column incomplete blocks within replicates (WILLIAMS and TALвот, 1993) with five replicates and three-tree row plots (five-tree row plots at Andhra Pradesh). Initial spacing was $2 \mathrm{~m}$ between rows and $1.5 \mathrm{~m}$ between trees within rows. Sites were cultivated by ploughing using tractors for clearing the existing vegetation and fertilized with a basal application of $50 \mathrm{~g}$ of NPK 17:17:17 fertilizer to each plant. Manual weed control was provided as required during the first two years.

The trees were measured for height and diameter at breast height over bark (dbh) 24 months after planting. Survival exceeded $90 \%$ at two sites and the lower survival of $80 \%$ at the third site, Sathyavedu, was largely the result of informal harvest by local people, so survival is not considered further. Individual trials were first analyzed with ASReml software (GILMOUR et al., 2002), using the following model:

$$
\begin{aligned}
\mathrm{Y}= & \mathrm{MEAN}+\mathrm{REPL}+\mathrm{PROV}+\mathrm{ROW}+ \\
& \mathrm{COL}+\mathrm{FAM}+\mathrm{PLOT}+\mathrm{RESID}
\end{aligned}
$$

where $\mathrm{Y}$ is the vector of observations, MEAN is the site mean, REPL and PROV are the replicate and provenance effects fitted as fixed factors, ROW, COL, FAM and PLOT are the incomplete row blocks, incomplete column blocks, family-within-provenance and plot effects fitted as random factors, and RESID is the vector of residuals. The significance of differences among provenances was examined using F-statistics based on Wald tests obtained from ASReml, and the significance of differences among families within provenances was examined using log-likelihood ratio tests. Within-provenance individual-tree heritabilities for height and dbh were calculated according to formula 2 :

$$
h^{2}=\frac{\sigma_{i^{2} / 0.3}}{\sigma_{r^{2}+\sigma_{r r t}^{2}+\sigma^{2}}^{2}}
$$

\begin{tabular}{|c|c|c|c|c|c|c|}
\hline Provenance & $\begin{array}{l}\text { CStRO } \\
\text { seedlot no. }\end{array}$ & Region' & $\begin{array}{l}\text { No. al } \\
\text { [amilies }\end{array}$ & $\begin{array}{l}\text { Latitude } \\
\text { (S) }\end{array}$ & $\begin{array}{c}\text { Longitude } \\
(1:)\end{array}$ & $\begin{array}{c}\text { Altitude } \\
\text { (ni) }\end{array}$ \\
\hline Gilberl River & 12963 & ald & 10 & $18+30$ & $142^{\prime \prime} 52^{*}$ & 250 \\
\hline limu Creek Pel ford & $14341-14353$ & Qld & 13 & $177^{02} 1^{\circ}$ & $144^{\prime \prime} 57^{r}$ & 460 \\
\hline Nolan Creek Si Wrotham Pl: & $14777-14788$ & Qld & 12 & $16^{n} 49^{r}$ & $144^{\prime \prime} 10^{r}$ & 240 \\
\hline 1:lixabcth Crock l: Wrothan l'k & $14789-14801$ & Qld & 12 & $16^{\circ} 40^{r}$ & $144^{\prime \prime} 01^{*}$ & 175 \\
\hline pelford & 16536 & ld & 5 & $17^{\circ} 20^{\circ}$ & $144 n 57^{r}$ & 490 \\
\hline W. Dimbulla-29km & 16539 & Qld & 4 & $17^{x} 10^{*}$ & $144 " 53^{\prime \prime}$ & 42 \\
\hline W. Eimbulla $-24 \mathrm{~km}$ & 16540 & ald & 5 & $17^{1} 10^{r}$ & $144^{n} 56^{r}$ & 420 \\
\hline Kennedy River & 18242 & Qld & 11 & $15^{4} 27^{+}$ & $144^{\circ} 10^{+}$ & 85 \\
\hline Kennedy River & 18275 & ld & 20 & $15^{+2} 26^{\circ}$ & $144^{\prime \prime} 11^{*}$ & 60 \\
\hline Laura IRiver & 18276 & Ild & 13 & $15^{4} 39^{r}$ & $14431^{\circ}$ & 100 \\
\hline Morchead IR & 19010 & ald & 12 & $15^{\circ} 02^{+}$ & $143^{\circ} 40^{+}$ & 60 \\
\hline Victoria River & 13928 & $\mathrm{NH}$ & 10 & $15^{4} 35^{r}$ & $1,31^{0} 02^{r}$ & 35 \\
\hline Cockatoo Creck & 13929 & $\mathrm{NI}^{\circ}$ & 10 & $15^{t} 38^{t}$ & $129^{\circ} 01^{+}$ & 50 \\
\hline WSW Kalherinc- $20 \mathrm{~km}$ & 18987 & $\mathrm{NH}$ & 15 & $14^{*} 33^{r}$ & $132^{0} 04^{r}$ & 95 \\
\hline Ord Rivet & 13931 & WA & 10 & 1728 & $127^{n} 58^{r}$ & 280 \\
\hline N fitzroy Crossing & 13933 & WA & 10 & $18^{4} 06^{+}$ & $125^{\circ} 42^{*}$ & 110 \\
\hline Lennard \& Barker & 15320 & WA & 10 & $17^{\prime 2} 20^{\prime}$ & 12445 & 70 \\
\hline De Groy River & 18658 & WA & 10 & $20^{\prime \prime} 12^{4}$ & $119^{\circ} 12^{\prime}$ & 70 \\
\hline Maturalayam & & Eocal & 11 & $11^{12} 18^{9^{7}}$ & $7655^{\prime}$ & 411 \\
\hline Siruntugai & & Local & 3 & $11^{* 1} 19^{1.7}$ & $76^{\prime 6} 56^{\prime}$ & 435 \\
\hline Sctumadai & & Local & 1 & $10^{13} 34^{17}$ & $76^{\circ} 56^{\prime}$ & 521 \\
\hline
\end{tabular}

Table 1. - Details of provenances used in Eucalyptus camaldulensis progeny trials.

${ }^{1}$ Qld = Queensland, NT = Northern Territory, WA = Western Australia.

${ }^{2}$ Not all families were tested in each trial.

${ }^{3}$ Latitude is $\mathrm{N}$. 


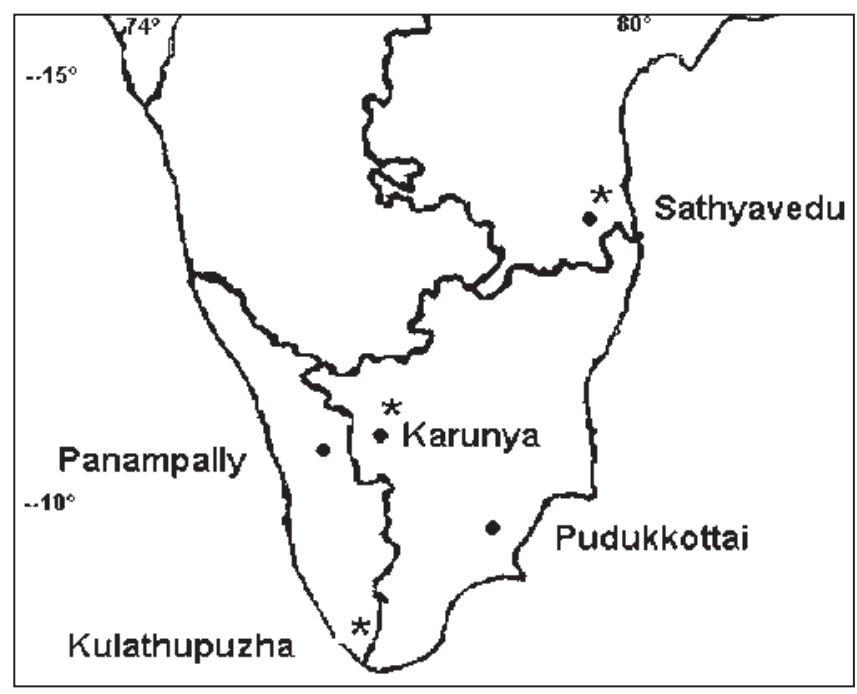

Figure 1. - Locations of progeny trials and clonal trials in southern India.

- = progeny trial ${ }^{*}=$ clone trial

where $h^{2}$ is heritability, and $\sigma_{f}^{2}, \sigma_{\text {plot }}^{2}$ and $\sigma_{e}^{2}$ are the variance components for

FAM, PLOT and RESID respectively. This formula assumes a coefficient of relationship of 0.3 for open-pollinated families of $E$. camaldulensis, which is known to have high rates of out-crossing in natural populations (BUTCHER and Williams, 2003). The significance of provenance-by-site interactions and estimates of acrosssite, within-provenance heritabilities for height and dbh were obtained by analysing the combined data set from all three sites using a model similar to (1) which incorporated site, provenance within site and replicate within site as additional fixed effects.

\section{Evaluation of clones}

Trees judged outstanding in terms of their vigour and stem form were selected from superior families and provenances in the three provenance-family trials and a further seven SSOs, SPAs and PRSs. Seventy-eight clones of $E$. camaldulensis and 27 clones of $E$. tereticornis were vegetatively propagated from basal coppice of the selected ortets and tested at from one to three locations (Table 2). Nine commercial clones from Andhra Pradesh and four commercial clones from Kerala with known superior performance in their regions of origin were included in the trials. Control seedlots of superior natural provenances from among Laura River, Kennedy River, Petford and Morehead River (Queensland) provenances of $E$. camaldulensis and Helenvale (Queensland) provenance of $E$. tereticornis were also included in the trials. Thus four "taxa" were evaluated in the clonal trials, namely $E$. camaldulensis clones and $E$. tereticornis clones from the IFGTB improvement program, commercial clones and control seedlots. The trials were laid out using randomized alpha designs with incomplete row and column blocks within replicates. Trials had five replicates and either three-tree plots (at Karunya and Sathyavedu) or two-tree plots (at Kulathupuzha), and spacing of $3 \mathrm{~m}$ between rows and $2 \mathrm{~m}$ between trees within rows. At each trial, height and dbh of all trees were measured at age 3 years. At the Karunya trial, wood cores were collected at breast height from either three or four trees from each clone or seedlot using a $5 \mathrm{~mm}$ increment corer. Core volume was estimated by the water displacement method and cores were then dried at $105^{\circ} \mathrm{C}$ and oven-dry weight measured. Basic wood density was calculated as the ratio of oven-dry weight to green core volume.

As with the family trials, analyses of the data from the clonal trials were carried out in two stages. For each site, mixed-model analyses were conducted for height and dbh using the following model:

$$
\begin{aligned}
\mathrm{Y}= & \mathrm{MEAN}+\mathrm{REPL}+\mathrm{TAXON}+\mathrm{ROW}+ \\
& \mathrm{COL}+\mathrm{CLONE}+\mathrm{PLOT}+\mathrm{RESID}
\end{aligned}
$$

where $\mathrm{Y}$ is the vector of observations, MEAN is the site mean, REPL and TAXON are the replicate and taxon effects fitted as fixed factors, ROW, COL, CLONE and

Table 2. - Details of trial locations of Eucalyptus provenance-progeny tests and clonal tests in

\begin{tabular}{|c|c|c|c|c|c|}
\hline & \multicolumn{5}{|c|}{ Location } \\
\hline & Panampally & Pudukkottai & Sathyavedu & Karunya & Kulathippuzha \\
\hline State & Kerala & Tami] Nadu & Andht'a Pladexl1 & Tattuil Nadu & Korala \\
\hline Latjtude & $10152 \mathrm{~N}$ & $10^{\prime \prime} 23^{\circ} \mathrm{N}$ & $13^{\circ} 25^{\prime} \mathrm{N}$ & $11^{\prime \prime} 00^{\prime} \mathrm{N}$ & $8501 \mathrm{~N}$ \\
\hline Longitude & $76^{\circ} 46^{\prime} \mathrm{E}$ & $78^{\prime \prime} 49^{\prime} \mathrm{F}$. & $79^{\prime \prime} 57^{\prime} \mathrm{F}$ & $7658^{\prime} \mathrm{F}$ & $77 \mathrm{IS}^{-1} \mathrm{E}$ \\
\hline Altitude (Ju) & 400 & 180 & 215 & 460 & 230 \\
\hline $\begin{array}{l}\text { Mean annual } \\
\text { raintall (m13) }\end{array}$ & 1400 & 650 & 1150 & 950 & 2800 \\
\hline Soil typt & $\begin{array}{l}\text { Sandy clay } \\
\text { loamn }\end{array}$ & Sandy loam & Loam & C.lay loam & Loam \\
\hline Soil plI & 6.0 & 6.5 & 5.9 & 6.2 & 5.6 \\
\hline $\begin{array}{l}\text { No. of promenamees } \\
\text { tested }\end{array}$ & 21 & 21 & 15 & & \\
\hline $\begin{array}{l}\text { No. of families } \\
\text { tested }\end{array}$ & 182 & 176 & 132 & & \\
\hline 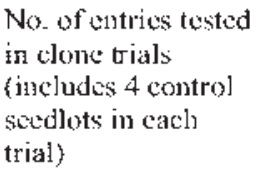 & & & 80 & 100 & 50 \\
\hline
\end{tabular}
southern India. 
PLOT are the incomplete row blocks, incomplete column blocks, clone-within-taxon and plot effects fitted as random factors, and RESID is the vector of residuals. Incomplete blocking factors were dropped from the models if their variance component did not exceed its standard error. The significance of differences between taxa was determined using F-statistics based on Wald tests obtained from ASReml.

The analyses for height and dbh were then repeated but with taxa omitted from the model, to obtain best linear unbiased predictions (BLUPs) for all individual clones and control seedlots. Clonal repeatabilities and their standard errors were then calculated using ASReml according to the formula:

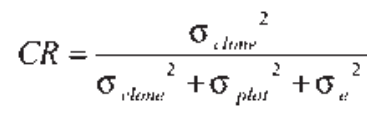

where CR is clonal repeatability, and $\sigma_{\text {clone }}^{2}, \sigma_{\text {plot }}^{2}$ and $\sigma_{e}^{2}$ are the variance components for CLONE, PLOT and RESID respectively. The control seedlots were excluded from the data sets for the calculation of clonal repeatability.
To provide an overall measure of growth performance of each treatment at each site, a conical volume index was calculated from the individual treatment height and dbh BLUP values as follows: volume index = height (in $\mathrm{m}) * \mathrm{dbh}$ (in $\mathrm{cm})^{2} * \pi / 12$. Gains in deployment, according to this volume index, were calculated on a percentage basis for each site by comparing the mean volume, according to the index, of the best (approximately) $10 \%$ of clones (10 best clones at Karunya, 8 best at Sathyavedu and 5 best at Kulathaphuzu) against the mean volume of all clones at that site, and against the volume of the best-performing natural provenance seedlot, which was Laura River provenance of $E$. camaldulensis at all sites.

Wood density at Karunya was analysed with ASReml using a mixed model in which replicates and taxa were declared as fixed effects and treatments within taxa (clones or seedlots) as random effects. The analysis was then repeated but with taxa omitted from the model, to obtain best linear unbiased predictions (BLUPs) of wood density for individual clones and control seedlots. Clonal repeatability for wood density was calculated using the formula:

Table 3. - Performance of E. camaldulensis provenances at two years.

\begin{tabular}{|c|c|c|c|c|c|c|c|}
\hline \multirow{3}{*}{ Provenance name } & \multirow{3}{*}{ Region' } & \multicolumn{6}{|c|}{ Trial location } \\
\hline & & \multicolumn{2}{|c|}{ Sathyavedu } & \multicolumn{2}{|c|}{ Pudukkottai } & \multicolumn{2}{|c|}{ Parnampalli } \\
\hline & & $\begin{array}{l}\text { I Jeight } \\
\text { (m) }\end{array}$ & $\begin{array}{l}\text { Dbh } \\
\text { (ctry) }\end{array}$ & $\begin{array}{l}\text { I Jeight } \\
\text { (m) }\end{array}$ & $\begin{array}{l}\text { Dbh } \\
\text { (cm) }\end{array}$ & $\begin{array}{l}\text { I Jeight } \\
\text { (m) }\end{array}$ & $\begin{array}{l}\text { Dbh } \\
\text { (cm) }\end{array}$ \\
\hline Gilbert Rjwor & Qld & 5.62 & 4.27 & 5.86 & 3.56 & 4.57 & 3.08 \\
\hline L:me Creck Petford & Qld & 5.22 & 3.79 & 6.07 & 3.68 & 4.42 & 2.79 \\
\hline Nolan Creek SL: Wrotham ]'K & Qld & 4.99 & 3.39 & 6.03 & 3.74 & 4.50 & 2.92 \\
\hline Lilizabel'n Ck l: Wrotham I'K & Qld & 5.70 & 4.52 & 5.93 & 3.67 & 4.37 & 2.84 \\
\hline Picl ford & Qld & 5.33 & 3.70 & 6.28 & 3.92 & 4.38 & 2.77 \\
\hline West ot Dimbulla by $29 \mathrm{~km}$ & Qld & * & * & 5.98 & 3.76 & 3.78 & 2.36 \\
\hline West of Dimbulla by $24 \mathrm{~km}$ & Qld & 5.04 & 3.47 & 6.04 & 3.81 & 4.31 & 2.76 \\
\hline Kennedy River 18242 & Qld & $*$ & $*$ & 6.03 & 3.78 & 4.28 & 2.95 \\
\hline Kennedy River 18275 & Qld & 5,06 & 3.55 & 5.91 & 3.65 & 4.44 & 2.90 \\
\hline Laura River & Qld & 5.09 & 3.51 & 5.95 & 3.77 & 4.10 & 2.66 \\
\hline Morthcad Rivet & Qld & 5.09 & 3.69 & 5.94 & 3.86 & 4.46 & 3.10 \\
\hline Victoria River & $\mathrm{NI}$ & 4.98 & 3.81 & 5.10 & 2.97 & 4.02 & 2.89 \\
\hline Cockatoo Greek & $\mathrm{NI}$ & 5.07 & 3.81 & 5.30 & 3.11 & 4.29 & 2.99 \\
\hline $20 \mathrm{~km}$ WSW ol Katherine & $\mathrm{NT}$ & 5.24 & 3.88 & 5.85 & 3.66 & 4.43 & 3.02 \\
\hline Ord lijwer & WA & 5.33 & 3.82 & 5.27 & 2.99 & 4.34 & 2.94 \\
\hline W Jizory Crossing & WA & 5.33 & 3.88 & 5.40 & 3.17 & 4.33 & 2.91 \\
\hline Lennard \& l3arker Rivers & WA & 5.10 & 3.72 & 5.42 & 3.16 & 4.44 & 3.05 \\
\hline De Grey liver & $W A$ & 4.95 & 3.53 & 5.26 & 3.12 & 4.29 & 2.84 \\
\hline Mollupalayam & Intiá & $*$ & * & 5.32 & 3.34 & 4.16 & 3.05 \\
\hline Sinumugai & India & * & * & 5.16 & 3.16 & 3.91 & 2.75 \\
\hline Setunnadai & India & $*$ & $*$ & 4.46 & 2.36 & 4.11 & 2.55 \\
\hline Site mear & & 5.2 & 3.79 & 5.68 & 3.46 & 4.33 & 2.92 \\
\hline $\begin{array}{l}\text { Average slandard crror of } \\
\text { difletence of moans }\end{array}$ & & 0.42 & 0.43 & 0.34 & 0.32 & 0.38 & 0.36 \\
\hline $\begin{array}{l}\text { Signilicanos of dillerences } \\
\text { butwest provenances }\end{array}$ & & $\mathrm{p}^{3}<0.00 \mathrm{l}$ & $P=0,00$ & $P<0.001$ & $P=0,00$ & $\mathrm{P}<0.001$ & $\mathrm{P}<0.0]$ \\
\hline $\begin{array}{l}\text { Significance of diflerenes } \\
\text { between families within } \\
\text { prowenares }\end{array}$ & & $P<0,05$ & $P<0,05$ & $P<0.05$ & $P<0,05$ & $P<0,05$ & $P<0,05$ \\
\hline
\end{tabular}




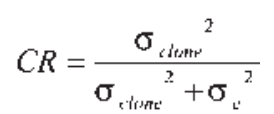

with control seedlots omitted from the data set for this calculation.

Clone-by-site interaction for height and dbh was examined using a restricted data set of the 30 clones that were common to all three trial sites. A simplified mixed model, omitting incomplete block effects, was used in which site and replicate within site were specified as fixed effects, and clone and site-by-clone interaction were specified as random effects. Across-site genetic correlations were calculated as:

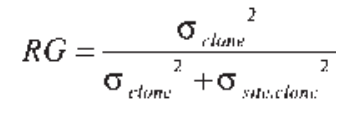

where $\sigma_{\text {clone }}{ }^{2}$ and $\sigma_{\text {site.clone }}{ }^{2}$ are the clone and site-by-clone variance components.

\section{Results}

\section{Provenance-family trials}

Best growth was observed at the dry Pudukkottai site, with an overall mean height of $5.68 \mathrm{~m}$ at 24 months after planting (Table 3). Growth was poorest at the higher-rainfall Panampally site (mean height of $4.33 \mathrm{~m}$ ) with the Sathyavedu site intermediate at $5.20 \mathrm{~m}$. Survival at 24 months was excellent at Pudukkottai (95\%) and Panampally (98\%) and rather lower at Sathyavedu (80\%).

Provenance differences for height and dbh were significant $(\mathrm{P}<0.001$ or $\mathrm{P}<0.01)$ at all sites (Table 3$)$. The across-site analysis of provenance performance showed that for both height and dbh, provenances differed significantly across the three sites $(\mathrm{P}<0.001)$ and the interaction of provenance and site was significant $(\mathrm{P}<0.001)$. Queensland provenances, particularly Petford, Kennedy River, Gilbert River, Laura River and Morehead River, showed clear superiority over provenances from the other two Australian regions at Pudukkottai. The differences among Australian provenances were less pronounced at Sathyavedu and Panampally, where there was no marked advantage of Queensland provenances over those from the Northern Territory and Western Australia. Provenances from all three regions in Australia displayed generally better
Table 4. - Estimates of within-provenance, individual-tree heritabilities for height and dbh at each site, and across sites.

$\begin{array}{lcc} & \text { Height } & \text { Dbh } \\ \text { Panampalli } & 0.08 \pm 0.05 & 0.10 \pm 0.04 \\ \text { Pudukkotai } & 0.19 \pm 0.05 & 0.19 \pm 0.04 \\ \text { Sathyavedu } & 0.16 \pm 0.06 & 0.10 \pm 0.05 \\ \text { Across sites } & 0.07 \pm 0.02 & 0.07 \pm 0.02\end{array}$

growth than the Mysore gum selections, which were tested only at Pudukkottai and Panampalli.

Within-provenance, individual-tree heritability estimates for height and dbh were low but significantly different from zero at all sites, ranging from 0.08 to 0.19 for height and 0.10 to 0.19 for dbh (Table 4). Pudukkottai had the highest heritabilities. Across-site heritability estimates, $0.07 \pm 0.02$ for both height and dbh, were lower than those at individual sites, suggesting substantial family-by-environment interaction.

\section{Clone trials}

Survival was generally high at Karunya and Kulathupuzha, with all taxa displaying mean survival of $89 \%$ or greater except for the seedling controls at Karunya for which survival averaged $50 \%$. At Sathyave$\mathrm{du}$, survival was lower, ranging from $55 \%$ (E. tereticornis clones) to $70 \%$ (E. camaldulensis clones and seedling controls) but many of the losses were the result of informal harvesting by nearby residents. At Kulathupuzha, many trees were affected by pink disease (Corticium salmonicolor Berk.) and leaf blight (Cylindrocladium quinqueseptatum Boedijn \& Reitsma), which reduced their growth but had not resulted in severe mortality at the age of assessment.

The best growth was recorded at Sathyavedu (Table 5), where overall mean height was $9.1 \mathrm{~m}$ at 36 months, followed by Karunya $(7.0 \mathrm{~m})$ and Kulathupuzha $(5.4 \mathrm{~m})$. At Sathyavedu and Karunya, the four taxa differed significantly $(\mathrm{P}<.01)$ in height and dbh. At Kulathupuzha, taxa differed significantly $(\mathrm{P}<0.05)$ only for $\mathrm{dbh}$.

The E. camaldulensis clones grew fastest on average at Sathyavedu, followed by the commercial clones and natural provenance seedlots, which showed comparable growth. E. tereticornis clones were inferior in growth at this site. The control seedlots performed poorly at Karunya, while many of the clones performed poorly at Kulathupuzha. The Laura River (Queensland) prove-

\begin{tabular}{|c|c|c|c|c|c|c|c|}
\hline & \multicolumn{3}{|c|}{ Karunya } & \multicolumn{2}{|c|}{ Suthyuvedu } & \multicolumn{2}{|c|}{ Kulathupuzha } \\
\hline Taxa & $\begin{array}{l}\text { Ileight } \\
\text { (trI) }\end{array}$ & $\begin{array}{l}\text { Dbh } \\
\text { (cm) }\end{array}$ & $\begin{array}{l}\text { Density } \\
\left(\mathrm{kg} \mathrm{m}^{-1}\right)\end{array}$ & $\begin{array}{l}\text { Height } \\
\text { (m) }\end{array}$ & $\begin{array}{l}\mathrm{Dbh} \\
(\mathrm{cm})\end{array}$ & $\begin{array}{l}\text { Height } \\
\text { (m) }\end{array}$ & $\begin{array}{l}\mathrm{Dbh} \\
(\mathrm{cm})\end{array}$ \\
\hline E. camaldulensis clones & 7.09 & 5.26 & 0.55 & 9.32 & 6.62 & 5.85 & 3,94 \\
\hline E. tereticomis clones & 6.81 & 5.06 & 0.50 & 8.79 & 6.14 & 6.03 & 3.94 \\
\hline control scedlots & 5.62 & 4.11 & 0.60 & 9.24 & 6.44 & 5.56 & 3.56 \\
\hline commercial clones & 7.05 & 5.06 & 0.56 & 8.96 & 6.71 & $6.0 \mathrm{I}$ & 4.34 \\
\hline Overall meast & 6.97 & 5.15 & 0.55 & 9.16 & 6.47 & 5.87 & 3.92 \\
\hline $\begin{array}{l}\text { Significance of } \\
\text { differences between taxa }\end{array}$ & $P<0.001$ & $P<0.001$ & n.s. & $P<0.01$ & $\mathrm{P}<0.01$ & n.s. & $P<0.05$ \\
\hline $\begin{array}{l}\text { Significance of } \\
\text { differences between } \\
\text { treatments within taxa }\end{array}$ & $P<0.001$ & $\mathrm{P}<0.00 \mathrm{I}$ & $\mathrm{P} \times 0.001$ & $P<0.01$ & $P<0.0 \mathrm{~L}$ & $\mathrm{p}<0.001$ & $\mathrm{P} \& 0,00 \mathrm{~L}$ \\
\hline
\end{tabular}

Table 5. - Mean height, dbh and wood basic density of four taxa in clone trials at 36 months.

n.s. $=$ not significant 
Table 6. - Clonal repeatabilities for height, dbh and wood basic density in clone trials at 36 months ( \pm standard errors).

\begin{tabular}{lccc} 
& Karunya & Sathyavedu & Kulathupuzht \\
\hline Height & $0.48(0.04)$ & $0.26(0.05)$ & $0.62(0.06)$ \\
Dbh & $0.28(0.04)$ & $0.24(0.05)$ & $0.55(0.06)$ \\
wood basic density & $0.67(0.04)$ & &
\end{tabular}

nance of $E$. camaldulensis was the best of the control seedlots at all three sites.

Differences between clones within taxa were highly significant $(\mathrm{P}<0.001)$ for both height and dbh (Table 5). Clonal repeatabilities for height and dbh were moderate to high, ranging from 0.29 for height and 0.25 for $\mathrm{dbh}$ at Sathayvedu to 0.62 for height and 0.55 for dbh at Kulathupuzha (Table 6). Ranked on the volume index, almost all clones (92 out of a total of 96) out-performed the Kennedy River provenance of $E$. camaldulensis at Karunya, whereas only 9 out of 76 clones at Sathyavedu and 4 out of 46 clones at Kulathupuzha out-performed Kennedy River E. camaldulensis (Table 7). The gains from deploying the best $10 \%$ of clones relative to Kennedy River $E$. camaldulensis varied greatly, being modest at Sathyavedu and Kulathupuzha (25\% and $35 \%$ respectively, Table 7 ), and much higher at Karunya (109\%). Across-site analysis of clonal performance calculated following the method of WiLLIAMs et al. (2002) confirmed significant $(\mathrm{P}<0.001)$ site-by-clone interaction for height and dbh (data not shown). The wider range of clonal rankings at Kulathupuzha also resulted in a very high deployment gain for the best clones relative to the mean of all clones tested there $(166 \%$, compared to $34 \%$ at Karunya and $62 \%$ at Sathyavedu).

Clones belonging to superior provenances of $E$. camaldulensis selected from IFGTB progeny trials, SPAs and PRSs were strongly represented among the $10 \%$ of fastest-growing clones at each of the three clonal trial sites (two of the top five clones ranked on volume index at Kulathupuzha, eight of the top ten clones at Karunya and six of the top eight clones at Sathyavedu). In contrast, IFGTB selections of E. tereticornis were only represented by one clone among the top five clones at Kulathupuzha. Commercial clones were among the top $10 \%$ of clones at each site (one at Kulathupuzha, one at Karunya and two at Sathyavedu).

Wood basic density at the Karunya trial ranged widely among clones, from a minimum of $450 \mathrm{~kg} \mathrm{~m}^{-3}$ to a maximum of $700 \mathrm{~kg} \mathrm{~m}^{-3}$. While the taxa did not differ significantly in their wood density, differences between individual clones and seedlots within taxa were significant $(\mathrm{P}<0.001$, Table 5). Clonal repeatability of wood density in this trial was high, at 0.67. (Table 6).

Across-site genetic correlations for the 30 clones planted at all sites were relatively low, at 0.40 for height and 0.34 for dbh.

\section{Discussion}

Though eucalypts have been planted in India for over a century, concerted genetic improvement programs based on a wide genetic base have been initiated only recently. Most of the improvement efforts have involved identifying superior provenances and selection of individuals for deployment as clones. The provenance-family trials reported here demonstrated substantial differences in the performance among the natural provenances of $E$. camaldulensis from Australia, and their superiority to selected families of the local Mysore Gum land race. Superior provenances of E. camaldulensis previously identified for the southern states of Andhra Pradesh (ChATURVedi et al., 1989), Tamil Nadu (KumarAVELU et al., 1995) and Karnataka (CHANDRA et al., 1994) are the same as those identified in this study, and include Petford, Gilbert, Kennedy, Morehead and Laura Rivers from Queensland.

Eucalyptus camaldulensis and E. tereticornis intergrade in parts of their natural range in Queensland (DorAN and Burgess, 1993). Certain superior provenances such as Laura and Morehead Rivers, now classified as $E$. camaldulensis subsp. simulata by BROOKER and KLEINIG (2004) were formerly identified as $E$. tereticornis and their performance in India has been reported as such (e.g. RAO, 1984) so comparisons of the performance of $E$. camaldulensis and $E$. tereticornis must be interpreted carefully. It appears that these two provenances and also the nearby Kennedy River provenance of $E$. camaldulensis are among the best-performing natural provenances in dry southern India.

The clear superiority of Queensland seedlots at Pudukkottai in Tamil Nadu suggests that the next generation E. camaldulensis breeding population for this dry region should be comprised primarily of selections from the best Queensland provenances. In support of this, Petford (Queensland) provenance was reported to perform well across several trials conducted by the Eucalyptus Research Centre in Andhra Pradesh where the annual rainfall is around $800 \mathrm{~mm}$ (CHATURVEDI et al., 1989). Selections belonging to seedlots from other regions in Australia (Northern Territory and Western Australia) could be retained in breeding populations for regions receiving higher rainfall. The local Mysore gum selections tested in the current study were below average in their growth performance at the two locations where they were tested. The inferiority of the Mysore gum land race to introduced natural provenances of E. camaldulensis supports the observation of BoLAND (1981) that the most suitable material was not being used for eucalypt planting programs in India. In contrast, local selections of $E$. camaldulensis made in Thailand were found to be on par with the best Queensland natural provenances of this species in three provenancefamily trials (PINYOPUSARERK et al., 1996). The Thailand trials tested a large set of 315 families incorporating most of the Australian families included in our trials. Growth rates of $E$. camaldulensis in the Thailand trials 
were rather higher than those reported here, site means for height at the three trial sites being 8.5, 8.1 and $5.3 \mathrm{~m}$ at age two years.

Early growth in our trials was much faster than growth of $E$. tereticornis provenances tested by GINWAL et al. (2004) at three sites in northern India, where site means for height at 21 months ranged from under $1 \mathrm{~m}$ to $2.7 \mathrm{~m}$. In these trials, local selections from the Indian land races likewise displayed slower growth than the better natural provenances of $E$. tereticornis from Australia. Interestingly, the fastest-growing seedlot in these E. tereticornis trials, from Walsh River, Queensland, is now considered to be $E$. camaldulensis subsp. simulata based on its seed colour and operculum shape (J. Doran, pers. comm. 2007).

Within-provenance heritabilities for height and dbh were significant in all three of our trials, demonstrating the potential for ongoing additive genetic gain in growth traits in successive generations of breeding, once breeding populations comprised of superior provenances have been assembled. Very similar within-provenance heritabilities, ranging from 0.06 to 0.17 for height and 0.05 to 0.13 for $\mathrm{dbh}$, were obtained at age two years in the three trials in Thailand (PINYOPUSARERK et al., 1996, values adjusted to account for the coefficient of relationship of 0.25 used by these authors). High rates of out-crossing demonstrated in natural populations of tropical E. camaldulensis (BUTCHER and WILLIAMS, 2003) and the large numbers of families tested, suggest the range of heritability estimates for this species across six sites provides a reliable guide to heritabilities for early-age growth traits at individual sites for this species. However, heritabilities for the individual sites are upwardly biased relative to the across-site heritabilities, because the estimates of additive genetic variance at individual sites incorporate the family-by-environment interactions. Corresponding within-provenance heritabilities for height at 21 months for $E$. tereticornis in northern India ranged from 0.11 to 0.29 across three sites GINWAL et al. (2004).

The dominance of $E$. camaldulensis in the top $10 \%$ of clones in the clone trials at each site is due in part to testing a relatively larger number of these clones (78 clones of $E$. camaldulensis, compared to 13 commercial clones and $27 \mathrm{E}$. tereticornis clones). Most of the commercially available clones included in the trials are those used for operational planting after field testing by the plantation companies in India, and they may include some interspecific hybrid clones (LAL et al., 1993; DAS and RAO, 1999). Some commercial clones were selected from provenance trials (FLORENCE et al., 2002). The newly developed IFGTB $E$. camaldulensis and $E$. tereti- cornis clones were selected from a very broad genetic base deployed in ten large field trials and plantings, which may account for the substantial numbers of superior new clones identified.

The fact that most clones outperformed the provenance seedlots at the comparatively dry environment (Karunya), whereas most clones were inferior to the best provenance seedlot at the high rainfall site (Kulathupuzha), demonstrates that clonal selections should not be transferred to contrasting environments without thorough testing. At Kulathupuzha many clones suffered from disease, reducing their growth. This contributed to the high level of clone-by-site interaction for the growth traits, reflected in the low across-site genetic correlations for height and dbh. It is somewhat surprising that few clones outperformed the Laura River provenance control at Sathyavedu, as about half of the IFGTB clones and most of the commercial clones had been selected from intermediate-rainfall plantings including the nearby $E$. camaldulensis progeny trial.

Volume production, wood basic density and pulp yield (expressed as a percentage of oven-dry wood) are three principal traits that drive the profitability of kraft pulp production (GREAVES et al., 1997). The wide range of wood densities obtained for individual clones at the Karunya trial (450-700 $\mathrm{kg} \mathrm{m}^{-3}$ ), and the high clonal repeatability of this trait, indicate that strong emphasis should be placed on wood density when selecting clones for further testing. Some of the clones exceed the optimum upper density for kraft pulp production of about $600 \mathrm{~kg} \mathrm{~m}^{-3}$ (HILlis and BROwN, 1984) at age three years, and wood density would increase further with increasing tree age (eucalypts are typically harvested on a rotation of about five years in southern India). Therefore, it cannot simply be assumed that those clones with the highest density should be favoured in the selection process. There was no strong relationship between the clonal BLUP values for wood density at Karunya and the corresponding values for clonal volume index (Spearman correlation coefficient $=0.10$ ), so there is potential to select for clones with both rapid growth and optimum wood density. A similar conclusion was reached by OsORIO et al. (2003) who found low genetic correlations between volume and wood basic density at ages three and six years in three clonal trials testing 29-65 clones of $E$. grandis in Colombia.

Evaluation of progeny and clones of $E$. camaldulensis and $E$. tereticornis across diverse environments in southern India has identified suitable provenances for low- and medium-rainfall sites. This has led to recent strong demand by planters over much of central and southern India for seed from the IFGTB seed orchards

Table 7. - Percentage deployment gain in volume index from deploying the best $10 \%$ of clones tested at each site, relative to mean of all clones and best control seedlot.

\begin{tabular}{lccc} 
& Karunya & Sathyavedu & Kulathupuzha \\
\hline$\%$ gain relative to mean of all clones & 34 & 62 & 166 \\
$\%$ gain relative to best control seedlot* & 109 & 25 & 35 \\
Number of clones outperforming best control & $92(96)$ & $9(76)$ & $4(46)$
\end{tabular}

seedlot (total number of clones tested)

* Laura River provenance of E. camaldulensis. 
developed from these superior provenances. Poor farmers who take up cultivation in such areas prefer orchard-sourced seedlings over clones as initial investment is low and success rate is high. As can be seen from Table 7, the gain in volume production from planting the best clones relative to the best natural provenance seedlot was relatively modest (of the order of $25-35 \%$ ) in the high and intermediate rainfall clonal trials, and may not be sufficient to outweigh the cost and complexity of clonal deployment. Large-scale enterprises that can afford high initial investment have favoured clonal plantations.

For the higher-rainfall region in Kerala, greater disease resistance will be required for the long-term success of eucalypt plantations. This will probably involve the development of interspecific hybrid clones involving more disease-tolerant species such as E. pellita F. Muell. and E. urophylla S. T. Blake (PotTs and DunGEY, 2004). E. camaldulensis as a pure species is adapted to low-tointermediate rainfall environments with a dry season of up to 8 months (ELDRIDGE et al., 1993). Interspecific hybrid clones may also have a role in the drier regions of southern India, and it appears likely that E. camaldulensis and/or $E$. tereticornis should be involved as parental species for these regions as most other candidate plantation species such as E. urophylla and $E$. grandis Hill ex Maiden are poorly adapted to the low annual rainfall and the long hot dry season prevailing there. Superior individuals of E. camaldulensis and $E$. tereticornis identified in the trials reported here are likely to play an important role in hybrid breeding as well as pure species breeding.

\section{Acknowledgments}

The support provided by the forest departments and forest development corporations of Kerala, Tamil Nadu and Andhra Pradesh in establishing trials is gratefully acknowledged. Financial support was provided by FORTIP and World Bank funded (FREEP) project and by the Australian Centre for International Agricultural Research, with additional support from CSIRO Forestry and Forest Products. The Director and staff of IFGTB provided support and encouragement in implementing the breeding program. Drs BRIAN BALTUNIS and WASHINGTON GAPARE are thanked for their reviews of an earlier draft of this paper.

\section{References}

BolAND, D. J. (1981): Eucalypt seed for Indian plantations from better Australian natural seed sources. Indian Forester 107, 125-134.

Brooker, I. and D. Kleinig (2004): Field Guide to the Eucalypts Volume 3: Northern Australia. Bloomings Books, Melbourne.

Butcher, P. A. and E. R. Williams (2003): Variation in outcrossing rates and growth in Eucalyptus camaldulensis from the Petford Region, Queensland; evidence of outbreeding depression. Silvae Genetica 51, 6-12.

Chandra, K. M., S. S. Patnaik and K. Gurumurthi (1992): Country report India. In: Tree Breeding and Propagation. Part II Regional Review and Country Reports. Field Document No.2, FAO/ UNDP Project RAS/88/025, Bangkok, pp. 49-68.
Chandra, B. K. J., G. S. Kariyappa and B. E. Manjunath (1994): Evaluation of Eucalyptus camaldulensis provenance trials in Karnataka. Indian Forester 120 , 670-676.

Chaturvedi, A. N., P. Sivati and D. V. Jayaramprasad (1989): Eucalyptus provenance trials in Andhra Pradesh. Indian Forester 115, 445-454.

DAS, S. K. and C. M. RAO (1999): High - yield Eucalyptus clonal plantations of A.P Forest Development Corporation Ltd. - A success story. Indian Forester 125, 1073-1081.

Dewees, P. A. and N. C. SAXenA (1995): Wood product markets as incentives for farmer tree growing. In: Arnold, J. E. M. and Dewees, P. A. (Eds.) "Tree management in farmer strategies: responses to agricultural intensification", Oxford University Press, Oxford, pp 198-241.

Doran, J. C. and I. P. BuRGESS (1993): Variation in floral bud morphology in the intergrading zones of Eucalyptus camaldulensis and E. tereticornis in northern Queensland. Commonwealth Forestry Review 72 (3): 198-202.

Doran, J. C., K. Pinyopusarerk, R. Arnold and C. E. HARWOOD (1996): Breeding Plan for Eucalyptus camaldulensis in Tamil Nadu. UNDP/FAO Regional Project on Improved Productivity of Man-Made Forests through Application of Technological Advances in Tree Breeding and Propagation. (RAS/91/004-FORTIP) 40p.

EldRIDGe, K. G., J. DAVidson, C. E. HaRwood and G. VAN WYK (1993): Eucalypt Domestication and Breeding. Oxford University Press.

Florence, M., M. Balasundaran and J. K. Sharma (2002): Clonal propagation of eucalypts in Kerala, India for disease resistance and high productivity. Proceedings, International Conference on Eucalypt Productivity. 10-15 November, 2002, Hobart, Tasmania. CRC for Sustainable Production Forestry and CSIRO Forest Products, Hobart. pp 33-34.

Gilmour, A. R., B. J. Gogel, B. R. Cullis, S. J. Welham and R. Thompson (2002): ASReml User Guide Release 1.0. VSN International, Oxford.

Ginwal, H. S., P. Kumar, V. K. Sharma, A. K. Mandal and C. E. HARWOOD (2004): Genetic variability and early growth performance of Eucalyptus tereticornis Sm. in provenance cum progeny trials in India. Silvae Genetica 53, 148-161.

Greaves, B. L., N. M. G. Borallho and C. A. Raymond (1997): Breeding objectives for plantation eucalypts grown for kraft pulp. Forest Science 43, 465-472.

HEGDE, R. and M. VARGHEse (2002): Selection and thinning in an unpedigreed seedling seed orchard of Eucalyptus camaldulensis Dehn. In: BAGCHI, S. K., VARGHese, M. and SidDAPPA (Eds.) Recent Eucalypt Research in India. Indian Council of Forestry Research and Education, Dehra Dun. pp 9-18.

Hillis, W. E. and A. G. Brown Eds. (1984): Eucalypts for Wood Production. CSIRO and Academic Press, Melbourne.

KaIKINI, N. S. (1961): Eucalyptus in Mysore state. Proceedings of the tenth All India Silvicultural Conference, Dehra Dun. Indian Council of Forestry Research and Education, Dehra Dun. pp 546-553.

KulKarni, H. D. (2002): Bhadrachalam clones of Eucalyptus - an achievement of ITC. Paper presented in international workshop "Forest Science and Forest Policy in the Asia-Pacific Region: Building Bridges to a Sustainable Future" July 16-19, 2002, Chennai, India. 
Kumaravelu, G., S. Jagdees, R. S. V. Rai and B. SAmpson (1995): Provenances of Eucalyptus camaldulensis Dehnh and E. tereticornis Sm suitable to South Indian conditions - results of an IUFRO trial. Annals of Forestry 3, 129-133.

Lal, P., H. D. Kulkarni and K. SRinivas (1993): Eucalyptus improvement programme of ITC Bhadrachalam Paper boards Ltd. In: VivekanANDAN, K., Subramanian, K. N., Zabala, N. Q. and Gurumurthi, K. (ed.) Proc. Workshop on Production of Improved Planting Material for Afforestation Programmes, 18-25 June, Coimbatore, India.

Midgley, S. J., J. W. Turnbull and K. Pinyopusarerk (2002): Industrial Acacias in Asia: Small brother or big competitor? In: WEI, R. P. and XU, D. (Eds.) Proc. International Symposium on Eucalyptus Plantations, September 1-6, 2002, Guangdong, China, pp 19-36.

Osorio, L. F., T. L. White and D. A. Hunber (2003): Ageage and trait-trait correlations for Eucalyptus grandis Hill ex Maiden and their implications for optimal selection age and design of clonal trials. Theoretical and Applied Genetics 106, 735-743.

Pinyopusarerk, K., J. C. Doran, E. R. Williams and P. WUSAWANICH (1996): Variation in growth of Eucalyptus camaldulensis provenances in Thailand. Forest Ecology and Management 87, 63-73.
PotTs, B. M. and H. S. Dungey (2004): Interspecific hybridization of Eucalyptus: key issues for breeders and geneticists. New Forests 27, 115-138.

RAO, D. V. (1984): Provenance trials of Eucalyptus. Indian Forester 110, 28-34.

Varghese, M., A. Nicodemus, B. Nagarajan and K. SubRAMANIAN (2000): Hybrid breakdown in Mysore gum and need for genetic improvement of Eucalyptus camaldulensis and E. tereticornis. Proceedings,QFRI/CRC-SPF Symposium on Hybrid breeding and Genetics of Forest Trees. April 9-14, Noosa, Australia. Queensland Forestry Research Institute, Gympie, pp 519-525.

VARGHESE, M., N. RAVI and R. HEGDE (2001): Seedling seed orchards of Eucalyptus tereticornis for improved productivity in plantations of Tamil Nadu, India. International Conference on Forestry and Forest Products Research (CFFPR), 2001, Kuala Lumpur, Malaysia, 1-3 October, 2001, pp 520-522.

WeI, X. and N. M. Borallho (1993): Genetic control of growth traits of Eucalyptus urophylla S.T. Blake in South East China. Silvae Genetica 47, 158-165.

Williams, E. R., A. C. Matheson and C. E. Harwood (2002: Experimental Design and Analysis for Tree Improvement, Second Edition. CSIRO, Melbourne.

Williams, E. R. and M. TALBOT (1993): ALPHA+ : Experimental design for variety trials. Design User Manual. CSIRO, Canberra and SASS, Edinburgh.

\title{
Short Note: Coefficients of Variation in Variables with Bounded Scales
}

\author{
By R. D. BuRDON ${ }^{*}$ \\ Senior Scientist, Genetics, Scion (New Zealand Forest Research Institute Ltd), \\ Private Bag 3020, Rotorua, New Zealand
}

(Received $23^{\text {th }}$ October 2007)

\begin{abstract}
With a variable that is recorded on a scale with fixed bounds, it can be appropriate to use for the denominator of the coefficient of variation the square root of the (sign-independent) product of the differences between the mean and the two bounds of the scale. A simple illustrative example is given.
\end{abstract}

Key words: coefficient of variation, subjective rating, subjective score, binary variables.

The coefficient of variation (CV), namely the standard deviation divided by the mean, is often very useful information for the breeder. In particular, the product of the phenotypic CV and the heritability is a direct measure of the potential for genetic improvement of a given trait. For an ordinary metric trait (e.g. a growth variable such as height) a CV is fully valid, although an extremely

*) E-Mail: burdon@scionresearch.com high CV may be an indicator of severe positive skewness. However, in tree improvement it is often necessary to address traits for which valid measures of CVs are not straightforward. Such traits include ones that in practice need to be assessed according to bounded scales (e.g. subjective straightness scores), or else have binary expression (e.g. survival). In such cases, the choice of a relevant mean for the denominator of a $\mathrm{CV}$ is problematic.

As an example, consider straightness, assessed on a $1-9$ scale $(1=$ very crooked to $9=$ very straight $)$. With a mean score of 3,3 would superficially be the denominator for the $\mathrm{CV}$, although it seems more realistic to use 2 as the denominator, this being the difference $3-1$. But if the scale is to be used as a measure of crookedness, one might use 6 (namely 9-3) as the denominator.

As a mean score for such a variable approaches a bound, the standard deviation will approach zero. Yet the alternative CVs will diverge widely according to 